\title{
Introduction to 2nd International Cell Death Research Congress 2018, Izmir, 1-4 November $2018^{\dagger}$
}

\author{
Betul Karademir ${ }^{1, \neq, *}$, Zekiye Altun ${ }^{2, \ddagger}$ and Semra Kocturk $3, \S$ \\ 1 Genetic and Metabolic Diseases Research and Investigation Center, School of Medicine, Marmara \\ University, 34722 İstanbul, Turkey \\ 2 Department of Basic Oncology, Institute of Oncology, Dokuz Eylul University, 35210 Izmir, Turkey; \\ zekiyesaltun@gmail.com \\ 3 Department of Biochemistry, Faculty of Medicine, Dokuz Eylül University, 35210 Izmir, Turkey; \\ semra.kocturk@deu.edu.tr \\ * Correspondence: betulkarademir@marmara.edu.tr; Tel: +90-216-4214432 \\ $\ddagger$ Scientific Secretary of 2nd International Cell Death Research Congress 2018. \\ $\S$ General Chair of 2nd International Cell Death Research Congress 2018. \\ t Presented at the 2nd International Cell Death Research Congress, Izmir, Turkey, 1-4 November 2018. \\ Published: 7 December 2018
}

International Cell Death Research Congress 2018, the II edition of the conference series, was held in IZMIR at Wyndham Grand Izmir Özdilek Hotel, from November 1 to 4, 2018 for the second time in Turkey, after Izmir 2016. This conference series were organized by Cell Death Research Society of Turkey (CDRS-Turkey).

International Cell Death Research Congress 2018 was attended by 180 participants, $90 \%$ of them came from academia and 10\% from industry and research facilities. 71 submissions were received for peer review, all being assigned to 3 reviewers. From the accepted ones, 40 oral presentations were selected and presented in 16 topics listed hereafter, with focus on "Cell Death in Diseases" and "New tools in Cell Death Research". 34 posters were presented and displayed during the entire duration of the conference.

\section{Scientific sessions have covered the following topics:}

1. Aging and senescence

2. Cancer

3. Immunity

4. Inflammation

5. Signaling pathways

6. Systems biology

7. Genetics and epigenetics

8. Drug delivery systems

9. Cell stress and metabolism

10. Types of cell death

11. Stem cell

12. Survival mechanisms

13. Vascular processes

14. Diseases

15. New tools in cell death research (Cell imaging, cell death research, culture systems) 
16. Targeted therapies

On Saturday 3 November, special workshops focused on "Flow Cytometry" was attended by 43 persons, "Microscopy" was attended by 5 people and "3D Bioprinting" was attended by 15 people. Special lectures were presented in these workshops by researchers and also by companies.

\section{Workshop Program}

\begin{tabular}{|l|l|}
\hline \multicolumn{2}{|l|}{ FLOW CYTOMETRY } \\
\hline $\begin{array}{l}\text { Use of Flow Cytometry for Detection of } \\
\text { Apoptotic Cell Death in Th17 Cells }\end{array}$ & Dr. Ayten Nalbant \\
\hline $\begin{array}{l}\text { Evaluation of NK and CTL Functions by Flow } \\
\text { Cytometry }\end{array}$ & Dr. Günnur Deniz \\
\hline $\begin{array}{l}\text { Attune NxT Flow Cytometer } \\
\text { MICROSCOPY }\end{array}$ & $\begin{array}{l}\text { MEDSANTEK: Turker Toktay } \\
\text { BECKMAN COULTER }\end{array}$ \\
\hline $\begin{array}{l}\text { Introduction to Microscope Systems and } \\
\text { Microscope Applications }\end{array}$ & İNCEKARALAR: Hakan Türk \\
\hline $\begin{array}{l}\text { Current Practices and New Trends in } \\
\text { Microscopy }\end{array}$ & İNCEKARALAR: Hakan Türk \\
\hline 3D BIOPRINTING & AXOLOTBIO: Can Garipoğlu \\
\hline $\begin{array}{l}\text {-What You Need to Know About The Basics of } \\
\text { Bioprinting }\end{array}$ & AXOLOTBIO: Can Garipoğlu \\
\hline Principle and Applications of Bioprinting &
\end{tabular}

2nd International Cell Death Research Congress 2018 was introduced by two keynote lectures.

Seamus Martin (President of ECDO), Smurfit Institute of Genetics, Trinity College Dublin, Ireland "Stress-Induced Inflammatory Functions Of Death Receptors"

Vasıf Hasırcı, Middle East Technical University, BIOMATEN, Biotechnology Research Unit, Ankara, Turkey

"Biomaterials as Cellular Microenvironment Mimics"

During each International Cell Death Research Congress, posters and oral presentations have been evaluated by a committee and best 3 to 4 poster and oral presentations have been awarded by CDRS-Turkey. This year first 3 poster and oral awards have been supported by CDRS-Turkey and 4th poster and oral awards have been supported by FEBS-Journal. These awards were discerned during the closing ceremony.

Oral presentation awards:

1st: OP-12, Nurselin Ates, Ayten Nalbant, Volkan Seyrantepe. "INVESTIGATION OF REDOX HOMEOSTASIS IN EARLY-ONSET TAY-SACHS MOUSE MODEL”.

2nd: OP-31, Kerem Teralı, “IDENTIFICATION OF THE FGFR3G380R MUTANT AS A LIKELY CAUSE OF PSYCHOMOTOR DELAY IN AN ACHONDROPLASTIC CHILD: A COMBINED CLINICAL EXOME SEQUENCING AND BIOMOLECULAR MODELING APPROACH". 
3rd: OP-11, Tuğba Erkmen, Belgin Sert Serdar, Halil Ateş, Mehmet Korkmaz, Semra Koçtürk. “APOPTOTIC EFFECT OF BORON DERIVATIVES ON HL-60 ACUTE PROMYELOCYTIC LEUKEMIA CELL LINE".

4th: OP-27, Zekiye Altun, Burçin Baran, Safiye Aktaş,Hong Ling, Nur Olgun. "WHOLE EXOME SEQUENCING ANALYSIS OF GOOD AND BAD PROGNOSTIC NEUROBLASTOMA PATIENTS (ON THE BEHALF OF TURKISH PEDIATRIC ONCOLOGY GROUP)".

Poster presentation awards:

1st: PP-24, Ayse Tarbin Jannuzzi, Gulce Sari, Ayse Mine Yilmaz, Betul Karademir, Buket Alpertunga. "PROTEASOMAL INHIBITION WITH BORTEZOMIB CAUSES SELECTIVE AUTOPHAGY UPREGULATION AND PERINUCLEAR CLUSTERING OF MITOCHONDRIA IN HUMAN NEURONAL CELLS".

2nd: PP-20, Sema Arslan, Semra Unal, Tilbe Gokce, Beste Melek Atasoy, Oguzhan Gunduz, Betul Karademir. "COMBINATION OF FIRST GENERATION PROTEASOME INHIBITOR BORTEZOMIB WITH TEMOZOLOMIDE AND RADIOTHERAPY IN GLIOBLASTOMA 2D AND 3D CELL CULTURES".

3rd: PP-15, Belgin Sever Mehlika Dilek Altıntop, Elif Kaya Tilki, Miriş Dikmen, Ahmet Özdemir. "ANTIPROLIFERATIVE EFFECTS OF A SERIES OF PYRAZOLINES ON LUNG CANCER". 4th: PP-9, Derya Bulut, Ajda Coker- Gurkan, Recep Genc, Elif Damla Arisan. "AUTOCRINE GROWTH HORMONE MEDIATED CURCUMIN RESISTANCE OVERCAME BY AUTOPHAGY INHIBITION BY BAFILOMYCIN IN MDA-MB-231 AND T47D BREAST CANCER CELLS".

We thank all persons who contributed to the organization of this conference, either for logistics or for scientific committees, and obviously all attendees who contributed to the scientific success of this conference and International Cell Death Research Congress 2018 Sponsors and Exhibitors.

(C) 2018 by the authors. Licensee MDPI, Basel, Switzerland. This article is an open access article distributed under the terms and conditions of the Creative Commons Attribution (CC BY) license (http://creativecommons.org/licenses/by/4.0/). 